\title{
Mobility of metals in river sediments from a watershed in the Iron Quadrangle, Brazil
}

\begin{abstract}
Lilian de Souza Marques ${ }^{* 1}$
Deyse Almeida dos Reis ${ }^{1}$

Laura Pereira do Nascimento ${ }^{1}$

Edilson Gonçalves Oliveira ${ }^{1}$

Aníbal da Fonseca Santiago ${ }^{2}$

Hubert Mathias Peter Roeser ${ }^{3}$
\end{abstract}

1 Post-Graduation Program in Environmental Engineering

Federal University of Ouro Preto

Campus Universitário Morro do Cruzeiro, s/n

Ouro Preto MG Brazil.

CEP 35400-000

${ }^{2}$ Department of Civil Engineering

Escola de Minas

Federal University of Ouro Preto

Campus Universitário Morro do Cruzeiro, s/n

Ouro Preto MG Brazil.

CEP $35400-000$

${ }^{3}$ Department of Environmental Engineering,

Escola de Minas

Federal University of Ouro Preto

Campus Universitário Morro do Cruzeiro, s/n

Ouro Preto MG Brazil.

CEP 35400-000

* Corresponding author:

smbio.lilian@gmail.com

\section{RESUMO}

A dinâmica do comportamento de metais em ambientes de água doce tem sido um dos principais focos de monitoramento ambiental nos últimos anos. O presente estudo investigou a distribuição de metais pesados nos sedimentos fluviais da bacia do rio Santa Bárbara (Minas Gerais, Brasil). A área de estudo sofreu com problemas relacionados à mineração e várias atividades de alto impacto, como agricultura, silvicultura e reflorestamento para produção de carvão vegetal. Os sedimentos superficiais foram coletados em quatro pontos nos rios Conceição, Caraça e Santa Bárbara. Esses sedimentos foram analisados quanto a frações trocáveis, redutíveis, oxidáveis e residuais, através do procedimento de extração sequencial proposto pelo European Community Bureau of Reference (BCR). Os resultados indicam que o $\mathrm{Cd}$ e $\mathrm{Pb}$ estão presentes principalmente na fração redutível, enquanto $\mathrm{Fe}, \mathrm{Ni}, \mathrm{Cr}$ e $\mathrm{Zn}$ foram predominantemente encontrados na fração residual, $\mathrm{Mn}$ e $\mathrm{Cu}$ são os elementos que proporcionalmente apresentam frações mais trocáveis e maior mobilidade. Fatores como $\mathrm{pH}$ e potencial redox influenciam diversos processos que alteram a mobilidade de metais, como adsorção e complexação. Os valores desses parâmetros mostraram que os pontos amostrados possuem características redutoras e ácidas. A identificação das etapas geoquímicas dos metais nos sedimentos permitiu a compreensão da contaminação no meio e a identificação de possíveis fontes. Isso possibilita a avaliação da qualidade dos sedimentos na microbacia estudada e serve de referência para o monitoramento do efeito antrópico ao meio ambiente.

Palavras-Chave: Rio Santa Bárbara, mineração de ferro, extração sequencial, elementos traço.

\section{ABSTRACT}

The dynamics of the behavior of metals in freshwater environments has been one of the main focuses of environmental monitoring in the last years. The present study investigated the distribution of heavy metals in the river sediments of the Santa Bárbara River Watershed (Minas Gerais, Brazil). The study area suffered from problems related to mining and several high impact activities, such as farming, forestry, and reforestation for charcoal production. Surface sediments were collected at four points in the Conceição, Caraça, and Santa Bárbara rivers. These sediments were analyzed for exchangeable, reducible, oxidizible, and residual fractions through the sequential extraction procedure that was proposed by the European Community Bureau of Reference (BCR). The results indicate that the $\mathrm{Cd}$ and $\mathrm{Pb}$ are mostly present in the reducible fraction, while $\mathrm{Fe}, \mathrm{Ni}, \mathrm{Cr}$, and $\mathrm{Zn}$ were predominantly found in the residual fraction, $\mathrm{Mn}$ and $\mathrm{Cu}$ are the elements that proportionally present more exchangeable fractions and greater mobility. Factors such as $\mathrm{pH}$ and redox potential influence several processes which alter the mobility of metals, such as adsorption and complexation. The values of these parameters have shown that the sampled points have reducing and acidic characteristics. The identification of the geochemical stages of metals in sediments allowed for the comprehension of the contamination in the medium and the identification of possible sources. This enables the assessment of the quality of the sediments in the studied watershed and serves as a reference for the monitoring of the anthropic effect to the environment.

Keywords: Santa Bárbara River, iron mining, sequential extraction, trace elements. 


\section{INTRODUCTION}

Understanding the dynamics of the behavior of metals in freshwater environments has been one of the main focuses of environmental monitoring studies in the last few years, which has been faced with the complexity of regulating, mitigating, and remediating contamination in water bodies (WARREN; HAACK, 2001). Metals can be distributed in water environments as soluble species in water, colloids, forms in suspension and in sedimentary phases. However, in contrast to organic pollutants, they cannot be removed through the natural decomposition process (PENG et al., 2009). This characteristic puts them among the most serious pollutants within the natural environment because they cause adverse effects to the biota due to their toxicity, persistence and capacity of bio-assimilation and bioaccumulation by organisms.

To conduct a risk assessment of environmental samples affected by metal contamination, it is necessary to characterize the proportions of the elements in their several forms. The assessment should also be conducted under a wide range of possible conditions in natural systems. Once deposited in sediments, the metals can be adsorbed and form complexes, such as carbonates, iron and manganese oxides, organic carbon and sulfides (BURUAEM et al., 2012). The formation of these complexes regulates distribution, mobility, bioavailability and, consequently, the metals' toxicity according to the environmental conditions (ZHANG et al., 2015).

The mobility of these metals depends on a number of factors, such as the characteristics of the sediments and the physical-chemical form of the metal. These factors determine how much the elements are mobile, labile, or available to the species living in a certain medium (CAPPUYNS, 2012). The change of phase is controlled by processes such as decomposition/re-suspension, sorption/adsorption, and complexation/decomplexation (RUIZ, 2001). These processes are mainly controlled by $\mathrm{pH}$, redox potential, and complexing agents dissolved in the organic matter (SALOMONS, 1998).

The determination of the mobility of these metals can be carried out through sequential extraction techniques (LI; CAI 2015). This is a very well-established method for the fractioning of metals content in soils and sediments. The process consists of the application of reagents for a series of continuous extractions in soil or sediment samples, using pre-defined solutions, while taking factors such as the type of reagent, concentration, temperature, and time into account. The fractions provide information on the proportion of the metal which is associated with a determined geochemical phase (BEVILACQUA et al., 2009). This enables the association of the chemical form of origin to the form of chemical or biological occurrence, in addition to its mobilization (CARVALHO et al., 2012).

Given the diversity of the extraction procedures, the Community Bureau of Reference (BCR), based on the modifications of the method proposed by TESSIER et al., (1979), has created a standardized extraction procedure in three stages, which are known as BCR (URE et al., 1993). This procedure can be used to obtain metals in the exchangeable, reducible (metals associated to iron and manganese oxides), oxidizable (metals associated to organic matter and sulfides), and residual (metals associated to non-silica fractions of the sediments) fractions. The first reference material was the BCR CRM 601, certifying five elements $(\mathrm{Cd}, \mathrm{Cu}, \mathrm{Cr}, \mathrm{Ni}, \mathrm{Pb}$, and $\mathrm{Zn}$ ). However, modifications were required because there were several potential sources of irreproducibility in the stages of extraction, with the most important variables being $\mathrm{pH}$ and Hydroxylamine chloride. The new, revised protocol, BCR 701, contains the required alterations and involved the increase in concentration of the Hydroxylamine chloride and $\mathrm{pH}$ adjustment (RAURET et al., 2001), improving the reproducibility as a function of the greater efficiency of dissolution of the reducible fraction of the analyzed matrix (NEMATI et al., 2009). The process is intended to minimize errors in data treatment and sample analysis. In addition, it also identifies the most suitable analytical procedure and provides reference material for a comparison of the results.

In this context, the aim of this study was evaluate the influence of human activities and the natural features in the geochemical stages of metals in bottom sediments of Santa Bárbara River, important tributary of the Doce River, using the reference BCR-701. We correlated the results with the lithological and anthropic factors that influence this watershed. 


\section{MATERIALS AND METHODS}

\subsection{REGION OF STUDY}

The Santa Bárbara River watershed has been intensively exploited by mineral extraction activities thanks to its location on the northeast portion of the Iron Quadrangle, a pre-Cambrian terrain with significant mining resources, especially gold and iron (COSTA et al., 2010). In addition to mineral extraction, several high impact economic

\subsection{SAMPLING STATIONS}

The surface sediments were collected during March 2015, in the following four locations: a tributary of the Conceição River (Point 1), and three points along the main course of the Santa Bárbara river watershed (Points 2, 3, and 4), as shown in Figure 1.

The sampling points were selected to allow the assessment of the contributions of both point and diffuse pollution in the river. Point $1(\mathrm{P} 1)$ receives all of the input of the Conceição River watershed, which has several mining activities for metal and non-metal minerals, including iron ore. Point 2 (P2) receives all of the contribution of the Conceição River and the Caraça stream, which activities have influenced the watershed, such as farming, forestry, and reforestation for charcoal production. The population of the watershed is estimated to be 200,000 people (Instituto Brasileiro de Geografia e Estatística or IBGE 2015). The soil is diversified and is formed by cambisols, latosols, outcrops and argisols.

includes mining processes added to domestic discharges. Point $3(\mathrm{P} 3)$ is influenced by contamination from the upstream points $\mathrm{P} 1$ and $\mathrm{P} 2$, in addition to domestic and industrial effluents, and it is the last point before the Peti dam, which was formed by the damming of the Santa Bárbara River. The Peti dam is used to generate electricity and it acts as a barrier that partially prevents the contamination flow throughout the course of the river (SILVA et al., 2009). Point 4 (P4) is the last sampling point of the watershed and it receives all of input from the portion of the Santa Bárbara River downstream the Peti dam.

\subsection{PHYSICAL AND CHEMICAL ANALYSIS OF SEDIMENTS}

We also analyzed in situ the amounts of $\mathrm{pH}$ and redox potential $\left(\mathrm{E}_{\mathrm{H}}\right)$ using portable digital multiparameter (Ultrameter II 6Psi, Myron L Company, USA).

The sediment samples were collected with the aid of a collecting scoop, and the material was conditioned in polyethylene bags. In the laboratory, the material was dried at room temperature and then their particles were disaggregated and homogenized using an agate mortar and pestle. The granulometric analysis was done

by sifting with 35 mesh, 70 mesh, 100 mesh, 230 mesh and <230mesh iron sieves,

\subsection{SEQUENTIAL EXTRACTION}

The sequential extraction assay was carried out with $1 \mathrm{~g}$ of sediment. The standards were prepared with the same extraction solutions to minimize the matrix effects during the determinations by atomic absorption. The glassware and plastic containers were washed with Extran 5\% detergent; they were then obtaining granulometric fractions of $500 \mu \mathrm{m}$, $0210 \mu \mathrm{m}, \quad 149 \mu \mathrm{m}, \quad 63 \mu \mathrm{m}$, and $<63 \mu \mathrm{m}$, respectively. This meant that the dominant granulometric fractions at each point were below $<63 \mu \mathrm{m}$, which were used in the sequential extraction procedure. The finest fraction samples (silt and clay $<63 \mu \mathrm{m}$ ) accumulate higher concentrations of contaminants than coarse particles (particles larger than $63 \mu \mathrm{m}$ ),

which determine their wide use in the evaluation models of metal fractions in sediments (FÖRSTNER, 2004; HOROWITZ, 1985).

rinsed and kept immersed in $\mathrm{HNO}_{3}(30 \%)$ for $24 \mathrm{~h}$, and they were then rinsed again with deionized water and dried in a kiln before initiating the procedure. All of the reagents had a high degree of analytical purity and the solutions were prepared using ultra-pure water, which was obtained from the purification 


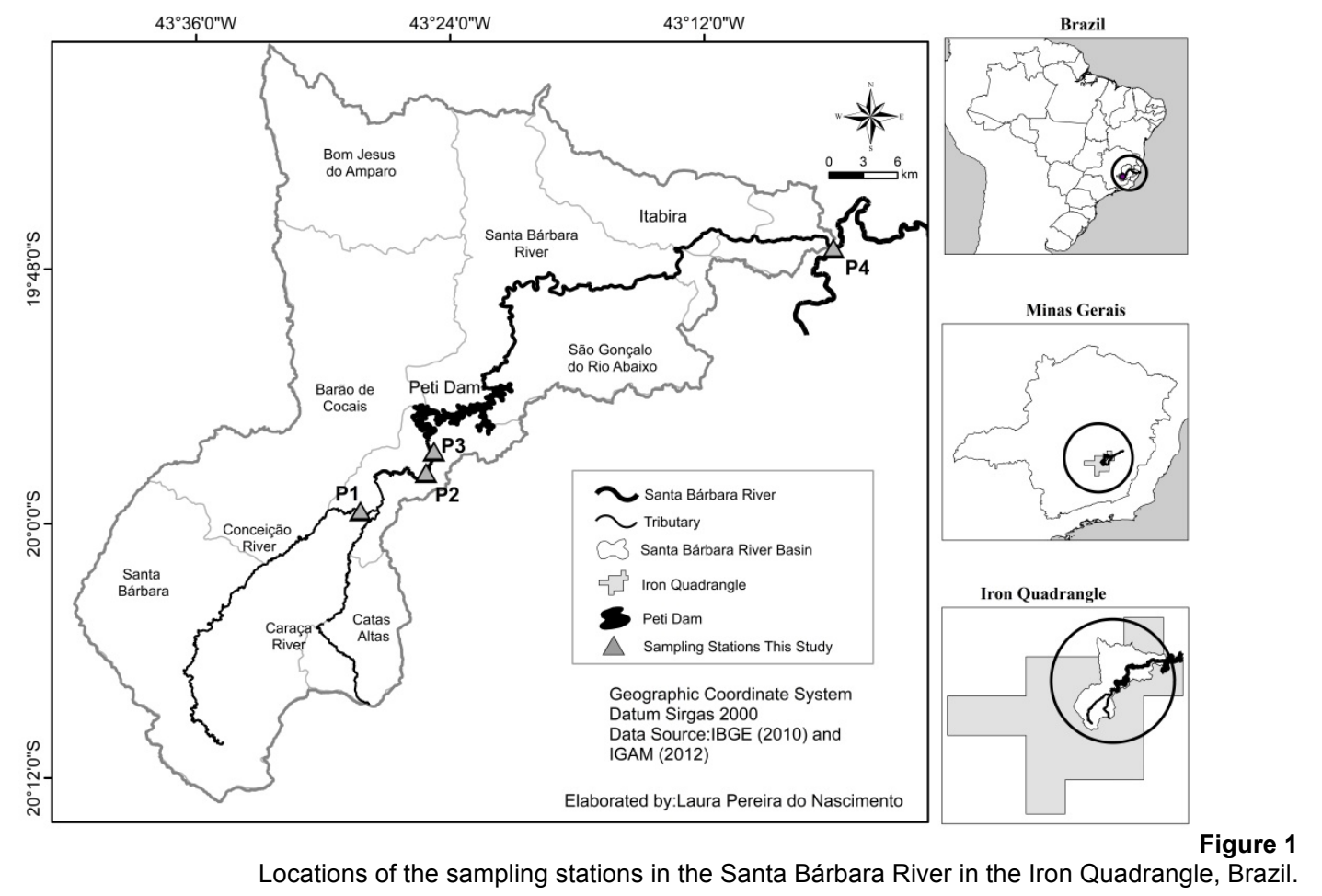

system of the Millipore Model Milli-Q.

For sequential extraction through the BCR701 method, the following reagents were used: $0.11 \mathrm{~mol} \mathrm{~L}^{-1}$ acetic acid $\left(\mathrm{CH}_{3} \mathrm{COOH}\right)$, $0.5 \mathrm{~mol} \mathrm{~L}^{-1}$ hydroxylamine hydrochloride $\left(\mathrm{NH}_{2} \mathrm{OH} . \mathrm{HCl}\right), 8.8 \mathrm{~mol} \mathrm{~L}^{-1}$ hydrogen peroxide $\left(\mathrm{H}_{2} \mathrm{O}_{2}\right)$, and $1 \mathrm{~mol} \mathrm{~L}^{-1}$ ammonium acetate $\left(\mathrm{CH}_{3} \mathrm{COONH}_{4}\right)$. The reagents used analyses were of the Synth (Brazil) brand.

The sequential extraction process was carried out in four samples with granulometry $<63 \mu \mathrm{m}$, based on the reference material BCR 701 of the Community Bureau of Reference. The samples were submitted in triplicate to the procedure proposed by Rauret et al (2001). The levels of $\mathrm{Cd}, \mathrm{Cr}, \mathrm{Cu}, \mathrm{Ni}, \mathrm{PB}, \mathrm{Zn}, \mathrm{Fe}$, and $\mathrm{Mn}$ were determined in the samples through the ICP- OES.

First Stage (F1): (Exchangeable Stage) $20 \mathrm{~mL}$ of $0.11 \mathrm{~mol} \mathrm{~L}^{-1}$ acetic acid was added to the previously weighed sediment. The tubes were submitted to agitation for $16 \mathrm{~h}$ at room temperature using an end-over-end type shaker (Heidolph Model REAX 2). The tubes were then centrifuged at $3000 \mathrm{rpm}$ for 30 minutes. The supernatant was transferred to a syringe coupled to a filter with a $0.45 \mu \mathrm{m}$ membrane. The filtrate was maintained at $4{ }^{\circ} \mathrm{C}$ for determination of the metals and metalloids. The residue was washed. After the addition of $20 \mathrm{~mL}$ of deionized water, the residue was submitted to agitation for 15 minutes and centrifuged at $3000 \mathrm{rpm}$ for 30 minutes. The supernatant obtained from the washing was discarded.

Second Stage (F2): (Reducible Stage) $20 \mathrm{~mL}$ of $0.5 \mathrm{~mol} \mathrm{~L}^{-1}$ hydroxylamine chloride acidified with $\mathrm{HNO}_{3} \quad\left(25 \mathrm{~mL}\right.$ of $\mathrm{HNO}_{3}$, $2 \mathrm{~mol} \mathrm{~L}^{-1}$ for $1000 \mathrm{~mL}$ of the solution) was added to the residue from the first stage. The same procedures as those used in the first stage were used for the agitation, centrifugation, and filtration.

Third Stage (F3): (Oxidizable Stage) $5 \mathrm{~mL}$ of the $8.8 \mathrm{~mol} \mathrm{~L}^{-1}$ hydrogen peroxide was added, drop by drop, to the residue from the second stage. The flask of the centrifuge was loosely capped and kept at room temperature for $1 \mathrm{~h}$, with occasional manual agitation. Then, the flask was put in a beaker that was placed in a water bath at $85 \pm 2^{\circ} \mathrm{C}$ for $1 \mathrm{~h}$, with occasional agitation in the first 30 minutes. With the open flask, the volume was reduced to $1.5 \mathrm{~mL}$. Again, another $5 \mathrm{~mL}$ of the $8.8 \mathrm{~mol} \mathrm{~L}^{-1}$ hydrogen peroxide was added and the flask was submitted to the same temperature until the volume reached approximately $0.5 \mathrm{~mL}$. After cooling, $20 \mathrm{~mL}$ of $1.0 \mathrm{~mol} \mathrm{~L}^{-1}$ ammonium acetate was added. For the extract separation, the same procedures as those used in the first stage were used for the agitation, centrifugation, and filtration.

Residual Stage (F4): At this stage, the residue from the third stage was transferred to a beaker using the minimum possible amount of deionized water. A volume of $4.65 \mathrm{~mL}$ of regal 
water $(3.50 \mathrm{~mL}$ of $\mathrm{HCl} 37 \% \mathrm{p} / \mathrm{p}$ and $1.15 \mathrm{~mL}$ of $\mathrm{HNO}_{3} 65 \% \mathrm{p} / \mathrm{p}$ ) was added. For digestion and filtration, the same digestion procedure with regal water was used. The filtered material was collected in a $25 \mathrm{~mL}$ volumetric flask.

The metal concentrations in the supernatant extracts obtained in the sequential extraction process were determined using an inductively coupled plasma/optical emission spectrometer (ICP-OES, Agilent Model 725, Agilent Technologies, Germany). Every procedure was carried out in the Environmental Geochemistry Laboratory (LGQA) at the Federal University of Ouro Preto (UFOP).

\section{RESULTS AND DISCUSSION}

\subsection{PHYSICAL AND CHEMICAL ANALYSIS OF SEDIMENTS}

The results of the present study show that all of the points are in acid and reducing medium. Lower $\mathrm{pH}$ and redox potential values were found in Points 1 and 2, respectively. The $\mathrm{pH}$ and redox values are shown in Table $\mathbf{1}$.

Table 1. $\mathrm{pH}$ and redox potential results for the sampling points

\begin{tabular}{lcc}
\hline & pH & Redox potential (mV) \\
\hline P1 & 6.32 & 143 \\
P2 & 6.87 & 107 \\
P3 & 6.60 & 134 \\
P4 & 6.95 & 140 \\
\hline
\end{tabular}

The $\mathrm{pH}$ and the redox potential are key parameters that directly influence the aquatic ecosystems due to their effects on the mobility of chemical species (PENG et al., 2009). A decrease in $\mathrm{pH}$ increases the concentration of free ions, causing the desorption of the colloidal and particulate forms, and the dissociation of some organic and inorganic complexes (MARKICH et al., 2002). The redox reactions control the oxidation state, and thus the mobility of the metals (VIOLANTE et al., 2010). Some $\mathrm{E}_{\mathrm{H}}$ values in different redox condition zones in sediments and soils can be interpreted as Salomons and Stigliani (1995):

- Oxidative zone $\left(\mathrm{E}_{\mathrm{H}}=+300 \mathrm{mV}\right)$ : value associated with aerobic respiration;

- Nitrate and $\mathrm{Mn}^{4+}$ reduction zone $\left(\mathrm{E}_{\mathrm{H}}\right.$ between +100 to $\left.+300 \mathrm{mV}\right)$ : value associated with facultative anaerobic respiration;

- $\mathrm{Fe}^{3+}$ reduction zone ( $\mathrm{E}_{\mathrm{H}}$ between -100 to $+100 \mathrm{mV}$ ): value associated with facultative anaerobic respiration;

- Sulfide reduction zone $\left(\mathrm{E}_{\mathrm{H}}\right.$ between -200 to $-100 \mathrm{mV}$ ): value associated with anaerobic respiration; and
- Methane formation zone $\left(\mathrm{E}_{\mathrm{H}}<-200 \mathrm{mV}\right)$ : value associated with anaerobic respiration.

The decrease in $\mathrm{pH}$ can promote the solubilization of carbonates and hydroxides, changing the desorption process of complex metallic cations by organic matter due to the competition of these cations with $\mathrm{H}^{+}$ions; therefore, the lower the $\mathrm{pH}$, the lower the metals retention capacity (QUINÁGLIA, 2006).

The redox potential of substances depends on two basic factors, which are the affinity of the molecules by electrons, and the concentration of reducers and oxidants in the medium, which is referred to as a redox pair DeLaune and Reddy (2005). The reducing agents are related to organic matter, and its several organic compounds and inorganic reducers, such as $\mathrm{NH}_{4}^{+}, \mathrm{Fe}^{2+}, \mathrm{Mn}^{2+}$. High redox potential values facilitate the sulfide and organic matter oxidation process, accelerating the release of complex/adsorbed metals (ZHANG et al., 2014). On the other hand, in reducing environments, sulfides form insoluble complexes and decrease mobility (Quináglia, 2006).

The results of the granulometric classification according to Conselho Nacional do Meio Ambiente or CONAMA 454/12 (BRAZIL, 2012) are shown in Table 2, based on the granulometric composition of the predominant fraction in the sampling points. Point 1 presented greater proportions of medium sand, whereas Points 2 and 4 showed the predominance of silt. Greater concentrations of clay were found in Point 3.

The sampling points presented a variation with respect to their granulometric classification. Points 2, 3 and 4 were the most relevant considering this parameter because they all contain greater fractions of clay or silt. 
Table 2. Dominant granulometric fraction of the sampling points

\begin{tabular}{lll}
\hline Samples & \multicolumn{1}{c}{ mm } & Classification \\
\hline P1 & 0.5 to 0.25 & Medium sand \\
P2 & 0.062 to 0.00394 & Silt \\
P3 & 0.00394 to 0.0002 & Clay \\
P4 & 0.062 to 0.00394 & Silt \\
\hline
\end{tabular}

The size of the particles which compose the sediments is essential for the comprehension of the occurrence of heavy metals in aquatic environments. It is one of the control parameters (MASLENNIKOVA et al., 2012) because the accumulation of contaminants and their distribution is inversely proportional to the size of the fraction (FÖRSTNER, 2004). Finer grains contain most of the metals associated with sediments, indicating a strong positive relationship between the decreasing

\subsection{SEQUENTIAL EXTRACTION}

The obtained fractions $\left(\mathrm{mg} \mathrm{kg}^{-1}\right.$ and \%) in each stage of the procedure are described in Table 3, and a graphic representation is shown in Figure 2. Stages 1, 2, 3, and 4 refer to the exchangeable, reducible (metals associated

\subsubsection{EXCHANGEABLE FRACTION}

The results indicate that cadmium, chrome, lead, and iron present minimum values, or even below the quantification limit of the device in this stage. The cadmium and lead fractions were below the quantification limit at all points (Fig. 2). At Point 1 , chrome had a percentage of $0.46 \%$ and at Point 2 it was $0.12 \%$ of the total. Points 3 and 4 were below the quantification limit. The values for iron were below $1 \%$ at all of the sampling points, as observed by other authors, such as Pereira et al. (2007).

The copper exchangeable fraction extracted in the samples shows that Point 1 presented the greatest amount in the exchangeable stage, with $49.90 \%$, followed by Point 2 with $22.50 \%$, Point 4 with $10.99 \%$, and Point 3 with $8.24 \%$. The high amount of the extracted fraction at the exchangeable stage at Point 1 is likely to be due to the adsorption of the metal to the abundant fine particles in the medium. These particles are exposed by the stirring of the soil. They are directly influenced by mining activities, leached to water bodies and co-precipitated, especially when carbonates are present in the area. Fine particles such as clay minerals present a sorting or ionic exchange size of the grain and the increase in metal concentration (HOROWITZ, 1985).

Finer sediments (clay and silt) are responsible for a significant portion of the transport of metals in water bodies, which are attached by adsorption to the surface of minerals, usually in particles $<63 \mu \mathrm{m}$ (CHAPMAN, 2002).

Clay minerals can obtain a negative net charge by ionic substitution where the ions $\mathrm{Si}^{+4}$ and $\mathrm{Al}^{+3}$ are replaced by similar size ions but with lower charge. The compensation of the negative charge occurs by association of cations (cation-exchange capacity) with the surface of the layers of these minerals, which is an important characteristic for sediments and colloids that present ion exchange capacity (MANAHAN, 2016).

with iron and manganese oxides), oxidizable (metals associated with organic matter and sulfides) and residual (metals associated with the non-silicate fraction of sediments) stages, respectively.

capacity caused by the electric charges in their crystallographic structure (RODRIGUES et al., 2015a). The affinity of $\mathrm{Cu}^{2+}$ with these minerals favors the adsorption process under the surface of carbonaceous minerals (FERREIRA; SANTANA, 2012). The obtained results are attributes the highest values in this fraction to the dissolution of minerals such as the Chalcopyrite $\left(\mathrm{CuFeS}_{2}\right)$ (CHI, 2013), which is abundant in the studied area.

Manganese followed the same pattern as copper, being in the exchangeable stage predominantly at Point 1 , with $42 \%$ of the total extracted, while Points 2, 3, and 4 presented between $26 \%$ and $29 \%$ of the extraction. These high concentrations indicate the affinity of $\mathrm{Mn}$ by carbonates (COPAJA et al., 2014). Mn is associated with minerals and humus, and in this stage, it is sensitive to environmental changes, modifying its mobility under acidic conditions (YANG et al., 2014). The manganese under the $\mathrm{Mn}^{2+}$ form, which is dominant in aquatic environments, is thermodynamically unstable in oxygenated environments, being oxidized to $\mathrm{Mn}^{3+}$ and $\mathrm{Mn}^{+4}$ (TRIBOVILLARD et al., 2006). Of all 
sampling points, Point 1 presented the highest redox potential value and the lowest $\mathrm{pH}$, which justifies the higher indices found in the exchangeable stage. Tack et al. (1996) investigated the function of $\mathrm{pH}$ in sediments influenced by oxidation processes, and showed that the Mn solubility linearly increases as $\mathrm{pH}$ decreases, which suggest its association with carbonates. They found that the extracted fractions occur as a function of the dissolution of $\mathrm{Ca}$ and $\mathrm{Mg}$ carbonates because $\mathrm{Mn}^{2+}$ can replace $\mathrm{Mg}^{2+}$ in dolomites and $\mathrm{Ca}^{2+}$ in calcites, which are carried to the sediments (GAO et al., 2010).

The highest zinc concentrations occurred at Point 1 with 17\%, and Points 2, 3, and 4 presented nearly $10 \%$ of the total extracted. Point 1 presents higher zinc concentration, despite the predominant sandy texture, which decreases the adsorption of metals in the sediments. The $\mathrm{pH}$ may have contributed to these results. According to Rieuwerts et al. (1998), the adsorption of $\mathrm{Zn}$ is significant when observed in $\mathrm{pH}$ between 5.0 and 6.5.

\subsubsection{REDUCIBLE FRACTION}

The result of the $\mathrm{Pb}$ extraction showed that this element was only extracted in the reducible fraction at all of the sampling points (Fig. 2). Lead is a metal that is known to be preferably associated with iron and manganese oxides (HEM, 1985) and can be released to the medium if the sediment is submitted to reducing conditions. This explains the proportions found in the reducible fractions, suggesting the importance of these ions in the transport of this element (YUAN et al., 2004). The higher levels can be from both anthropogenic and lithogenic sources. Point 4 receives contributions from domestic sewage, and possibly from sanitary landfill leachates, agricultural inputs and related to agriculture from the entire watershed downstream the Peti dam. These factors are responsible for the introduction of $\mathrm{Pb}$ in aquatic environments (OLIVEIRA; MARINS, 2011). Point 1 is extremely influenced by mineral processes that
Reddy et al. (1995) investigated the mobility of zinc in different media, and at $\mathrm{pH}$ levels of $6.6,5.0,4.0,3.0$, and 2.4 concluded that the availability of this element increases as $\mathrm{pH}$ decreases.

Nickel presented the highest percentage of the exchangeable stage, with $25.68 \%$, at Point 1 . Point 3 had nearly $9 \%$ of the total, and Point 2 had 7\%. For Point 4, the concentrations were below the quantification limit. The considerable fraction in Point 1 indicates potential pollution by recent contamination (RAURET, 1998).

Sorption-desorption processes at this stage can be affected by changes in the ionic composition of the water and variations of the $\mathrm{pH}$ values (TESSIER et al., 1979), which causes alterations in the liability of the elements (URE; DAVIDSON, 2008). Metals linked to this stage are considered potentially available for absorption by aquatic organisms (SINGH et al., 2005) because they are more easily released into the environment.

evidence large amounts of $\mathrm{Fe}$ and $\mathrm{Mn}$ that dominate the local lithology.

Cadmium presented similar pattern. At Points 1, 2, and 4 it was only found in the reducible fraction, while for Point 3 the fractions were below the quantification limit. The affinity with $\mathrm{Cd}$ in this stage is mostly linked to manganese oxides, or it can be coprecipitated, mainly on mineral surfaces (HEM 1985). Its mobility is moderate to low in acid and reducing environments (SMITH; HUYCK, 1999), respectively, which is a characteristic of all of the sampling points.

The $\mathrm{Cu}$ at Point 1 registered 27\%, at Point 2 it is the dominant fraction with $26 \%$, at Point 3 it was nearly $21 \%$, and at Point 4 it was $13 \%$. $\mathrm{Ni}$ equals $35 \%$ at Point $1,7 \%$ at Point 2 , $13 \%$ at Point 3 and it was below the quantification limit at Point 4. High $\mathrm{Ni}$ and $\mathrm{Cu}$ concentrations at Point 1 are related to the association of the metal to iron and manganese 


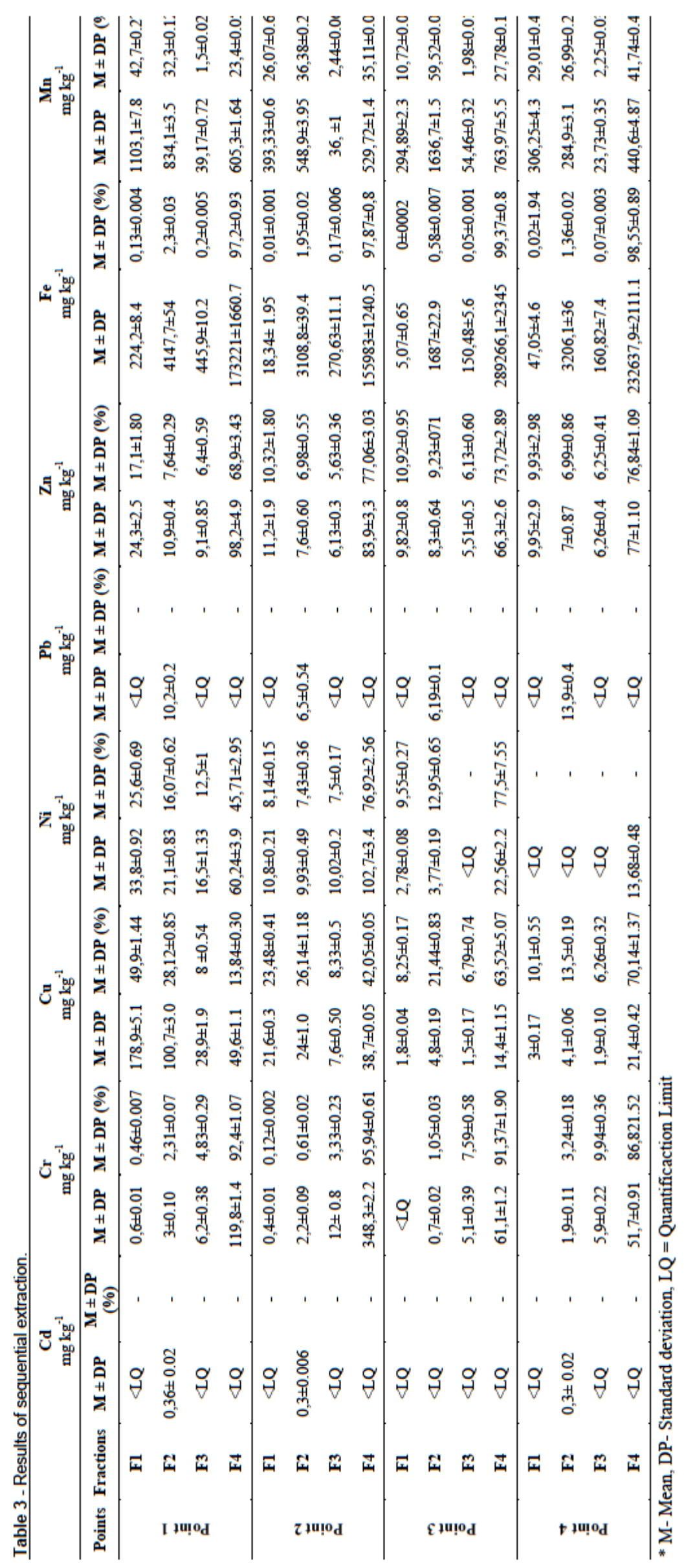



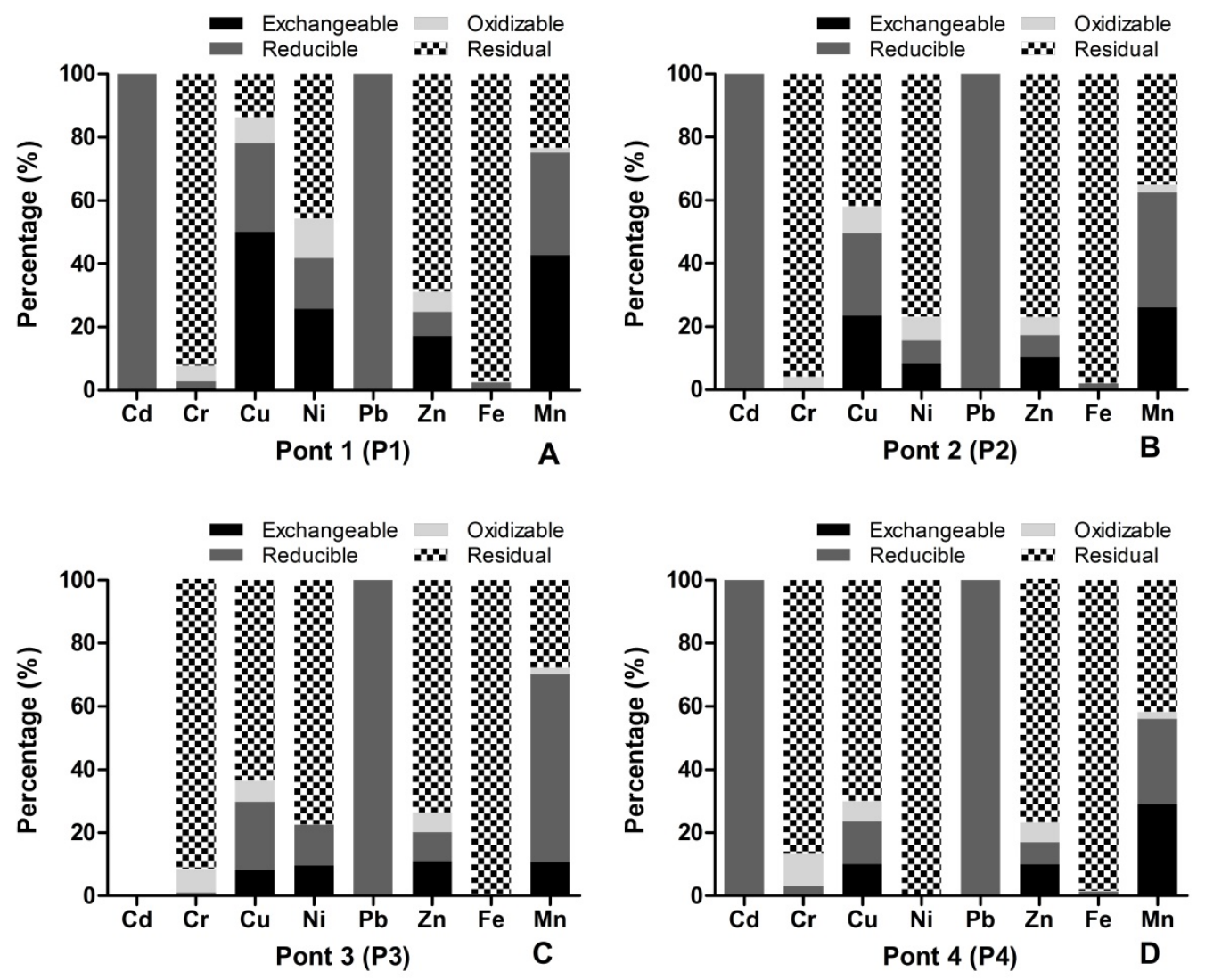

Figure 2

Results of the sequential extraction in Points 1 (A), 2 (B), 3 (C), and 4 (D).

oxides, which are released due to the instability of these elements under reducing conditions (YACOUB, 2012). $\mathrm{Fe}$ and $\mathrm{Mn}$ oxides are considered adsorbents and they are known to be easily leachable (TESSIER, 1979) and are abundant at this point due to the mining activities that influence the area.

The reducible fractions of $\mathrm{Mn}$ presented considerable concentrations at all points, and it was predominant at Points $2(36 \%)$ and 3 (59\%). These two points are located in urban areas and they both have intensive contamination by domestic and industrial effluent discharge. High Mn concentrations have been attributed to the reductive dissolution of manganese oxides, as defined by the following reaction (PETRUNIC et al., 2005).

$$
\mathrm{CH}_{2} \mathrm{O}+2 \mathrm{MnO}_{2(\mathrm{~S})}+4 \mathrm{H}^{+} \rightarrow 2 \mathrm{Mn}^{2+}+3 \mathrm{H}_{2} \mathrm{O}+\mathrm{CO}_{2}
$$

$\mathrm{Mn}$ and $\mathrm{Fe}$ oxides exhibit an especially high sorption capacity, and their production is mediated by the bacteria present in the sediments (MANAHAN, 2016). From this it

\subsubsection{OXIDIZABLE FRACTION}

The results indicate that the $\mathrm{Cd}$ and $\mathrm{Pb}$ concentrations were below the quantification limit at all of the sampling points (Fig. 2). For $\mathrm{Cr}, \mathrm{Zn}, \mathrm{Fe}$, and Mnthe indices signaled results below $8 \%$ in all of the samples. $\mathrm{Cu}$ ranged between $7-13 \%$ and Ni registered $12 \%$ at Point $1,8 \%$ at Point 2 and was below the quantification limit at Points 3 and 4. can be inferred that the mobility is increased by the action of these microorganisms. $\mathrm{Zn}$ registered between 7-9\%, whereas $\mathrm{Fe}$ and $\mathrm{Cu}$ were below $3 \%$ at all studied points.

The low metal concentrations at this stage are due to the location of the sampled points, which are within a region with high levels of humic substances (HS) (GONTIJO, 2012). High HS concentrations at the studied area due to the leaching of the pedological cover that is rich in humus, proving its capacity of complexation with metals such as $\mathrm{Cu}, \mathrm{Fe}, \mathrm{Mn}$, 
and $\mathrm{Zn}$ forming insoluble complexes. The insoluble complexes are formed as a result of the high molecular weight of the HS, which

\subsubsection{RESIDUAL FRACTION}

The concentrations that we found point to the predominance of the residual stage for $\mathrm{Cr}$ and $\mathrm{Fe}(>90 \%$ at all points), $\mathrm{Cu}(\mathrm{P} 4-70 \%$, P3-63\%, P2-42\%), Ni (P4 was the only quantified stage, $\mathrm{P} 3$ and $\mathrm{P} 2>75 \%$ and $\mathrm{P} 1>45 \%), \mathrm{Zn}(>70 \%$ at all points), and $\mathrm{Mn}$ (P4- $>40 \%$ ). The other points presented reduced values, while $\mathrm{Cd}$ and $\mathrm{Pb}$ did not register indices at this stage.

The $\mathrm{Cr}$ results at the four points showed that the transport of this metal is associated with crystalline particles, reflecting a geochemical contribution that mostly comes from the local rocks and soils, which are unavailable in the medium (BEVILACQUA et al., 2009). Although the residual fraction does not have a direct environmental importance for their lithogenic contributions, low values registered of this fraction can indicate the influence of aloctone pollutant sources that accumulate in the sediments (CORINGA et al., 2016). A similar situation was described by Abreu (2005) in the Cachoeira Stream, also in the Quadrangle Iron. In this case, despite having found high amounts of chrome in the samples, larger amounts were extracted in the residual stage, with nearly $91 \%$ to $93 \%$ of the concentration, and small amounts were found in the other stages.

\section{CONCLUSIONS}

The identification of the geochemical stages of metals in sediments allowed for the comprehension of the contamination in the medium and the identification of possible sources. This enables the assessment of the quality of the sediments in the studied watershed and serves as a reference for the monitoring of the anthropic effect to the environment.

This study showed a variation in the predominance of fractions in the analyzed elements. The results obtained in the sequential extraction indicate that cadmium was mainly found in the reducible stage, as was lead. Iron, nickel and chrome obtained the higher values extracted in the residual fraction, indicating low mobility in the medium. Zinc presented a slowly releases small amounts of metals depending on the decomposition processes in oxidant conditions (FILGUEIRAS et al.,2002).

The high levels of $\mathrm{Cu}$ in the residual fraction $(\mathrm{P} 2, \mathrm{P} 3$, and $\mathrm{P} 4)$ indicate its original mineralogy and reduced mobility in the watersediment interface (SÁENZ et al., 2003).

The dominance of the nickel proportion in the residual stage at all of the sampling points is in agreement with the literature (Yuan et al., 2004), and this element can be considered immobile.

According to the results, where the values exceed $70 \%$ at all points, $\mathrm{Zn}$ presents low mobility in the environment and is not available for biological processes. $\mathrm{Zn}$ in the residual fraction is usually associated with minerals such as magnetite $\mathrm{Fe}_{3} \mathrm{O}_{4}$ (RODRIGUES et al., 2015b), which is abundant in the studied area.

The results point out that $\mathrm{Fe}$ in this stage prevails, with over $97 \%$ of the total extracted in all samples. This indicates that it is mostly controlled by its mineralogy and the degree of weathering (SHARMIN et al., 2010). The obtained concentrations indicate that the element is chemically stable and biologically inactive.

The predominant $\mathrm{Mn}$ residual fraction at Point 4 represents a low direct risk to the environment because this metal presents stronger associations with the crystalline structure of the minerals.

pattern similar to that observed for $\mathrm{Fe}, \mathrm{Ni}$, and $\mathrm{Cr}$ with a higher fraction linked to the residual stage, but with some recorded small fractions at every stage. Manganese was mostly found in the reducible and exchangeable stages. Copper was the element that presented greater variation of the fractions at all points, especially Point 1 , with high concentrations in the exchangeable stage. Manganese and copper were the elements with greater mobility in the medium. Thus, small changes in the medium can offer these elements to the biota and cause bioaccumulation in the food chains. The granulometric analysis, redox potential and $\mathrm{pH}$ have proven to be important parameters for the comprehension of the distribution and mobility of these metals. 


\section{ACKNOWLEDGEMENTS}

This study was made possible by support from the Fundação de Amparo à Pesquisa do Estado de Minas Gerais (FAPEMIG), the Conselho Nacional de Desenvolvimento Científico e Tecnológico (CNPq), the Coordenação de Aperfeiçoamento de Pessoal

\section{REFERENCES}

ABREU A.T. 2005. Avaliação geoquímica ambiental da barragem do ribeirão da Cachoeira, sudeste do Quadrilátero Ferrífero, Ouro Preto, MG. Departamento de Geologia. Escola de Minas, Universidade Federal de Ouro Preto, $111 \mathrm{p}$.

BEVILACQUA J.E., SILVA I.S.D., LICHTIG J., ; MASINI J.C. 2009. Extração seletiva de metais pesados em sedimentos de fundo do Rio Tietê, São Paulo. Química Nova, 32:26-33.

BRAZIL- Conselho Nacional de Meio Ambiente or CONAMA. 2012. Resolução $\mathrm{n}^{\circ} 454$ de 01 de novembro de 2012. Estabelece as diretrizes gerais e os procedimentos referenciais para o gerenciamento do material a ser dragado em águas sob jurisdição nacional. Brasília, Brazil.

BURUAEM L.M., HORTELLANI M.A., SARKIS J.E., COSTA-LOTUFO L.V., ; ABESSA D.M. 2012. Contamination of port zone sediments by metals from Large Marine Ecosystems of Brazil. Marine pollution bulletin, 64:479-488.

CAPPUYNS V. 2012. A critical evaluation of single extractions from the SMT program to determine trace element mobility in sediments. Applied and Environmental Soil Science, 2012:1-15.

CARVALHO P.C.S., NEIVA A.M.R., ; SILVA M.M.V.G. 2012. Assessment to the potential mobility and toxicity of metals and metalloids in soils contaminated by old $\mathrm{Sb}-\mathrm{Au}$ and $\mathrm{As}-\mathrm{Au}$ mines (NW Portugal). Environmental Earth Sciences, 65:1215-1230.

CHAPMAN, D.V. 2002. Water quality assessments: a guide to the use of biota, sediments and water in environmental monitoring. CRC Press.

CHI C.Y. 2013. An investigation of the bioavailability of heavy metals in tailing run-off sediment at Devon Great Consols. The Plymouth Student Scientist, 6:211-309.

COPAJA S.V., MOLINA X., ; TESSADA R. 2014. Determination of heavy metals in Choapa river sediments using BCR sequential extraction procedure. Journal of the Chilean Chemical Society, 59:2353-2358.

CORINGA J.D.E.S., PEZZA L., CORINGA E.D.A.O., ; WEBER O.L.D.S. 2016. Geochemical distribution and bioavailability of trace metals in sediments of the Bento Gomes River, Poconé-MT, Brazil. Acta Amazonica, 46:161-174. de Nível Superior (CAPES), for which we are deeply thankful. We also thank Adriana Trópia de Abreu and Hermínio Naline Júnior from the Laboratório de Geoquímica Ambiental at Federal University of Ouro Preto for the ICP analysis, as well as Fundação Gorceix.

COSTA A.T., NALINI JR. H.A., CASTRO P.D.T.A., ; Tatumi S.H. 2010. Stratigraphic analysis and distribution of arsenic in quaternary sedimentary deposits of the southeastern portion of the Quadrilátero Ferrífero, basin of the Ribeirão Carmo, MG. Rem: Revista Escola de Minas, 63:703-714.

DELAUNE R.D., ; REDDY K.R. 2005. Redox potential. Encycl of Soils in the Environ, 3:366371

FERREIRA P.R.G., ; SANTANA G.P. 2012. Tratamento químico seletivo: uma especiação operacional. Scientia Amazonia, 1:40-48.

FILGUEIRAS A.V., LAVILLA I., ; BENDICHO C. 2002. Chemical sequential extraction for metal partitioning in environmental solid samples. Journal of Environmental Monitoring, 4:823-857.

FÖRSTNER U. 2004. Traceability of sediment analysis. TrAC Trends in Analytical Chemistry, 23:217-236.

GAO X., CHEN C.T.A., WANG G., XUE Q., TANG C., ; CHEN S. 2010. Environmental status of Daya Bay surface sediments inferred from a sequential extraction technique. Estuarine, Coastal and Shelf Science, 86:369378.

GONTIJO E.J.S. 2012. Interação entre substâncias húmicas aquáticas e elementos metálicos na porção leste do Quadrilátero Ferrífero. Programa de Pós-Graduação em Engenharia Ambiental, Universidade Federal de Ouro Preto, $92 \mathrm{p}$.

HEM J.D. 1985. Study and interpretation of the chemical characteristics of natural water. Department of the Interior, US Geological Survey.

HOROWITZ A.J. 1985. A primer on trace metalsediment chemistry (p. 67). Washington, DC: US Government Printing Office.

IBGE or Instituto Brasileiro de Geografia e Estatística. 2015. Estimativas da população residente no Brasil e Unidades da Federação. https://ibge.gov.br. Accessed 10 December 2018

LI Y. ; CAI Y. 2015. Mobility of toxic metals in sediments: Assessing methods and controlling factors. Journal of environmental sciences (China), 31:203-205.

MANAHAN S.E. 2016. Química ambiental. Bookman Editora.

MARKICH S.J., BROWN P.L., BATLEY G.E., 
APTE S.C., ; STAUBER J.L. 2001. Incorporating metal speciation and bioavailability into water quality guidelines for protecting aquatic ecosystems. Australasian Journal of Ecotoxicology, 7:109-122.

MASLENNIKOVA S., LARINA N., ; LARIN S. 2012. The effect of sediment grain size on heavy metal content. Lakes reservoirs and ponds, 6:43-54.

NEMATI K., BAKAR N.K.A., SOBHANZADEH E., ; ABAS M.R. 2009. A modification of the $\mathrm{BCR}$ sequential extraction procedure to investigate the potential mobility of copper and zinc in shrimp aquaculture sludge. Microchemical Journal, 92:165-169.

OLIVEIRA R.C. ; MARINS R.V. 2011. Dinâmica de metais-traço em solo e ambiente sedimentar estuarino como um fator determinante no aporte desses contaminantes para o ambiente aquático: Revisão. Revista Virtual de Química, 3:88-102.

PENG J.F., SONG Y.H., YUAN P., CUI X.Y., ; QIU G.L. 2009. The remediation of heavy metals contaminated sediment. Journal of hazardous materials, 161:633-640.

PEREIRA J.C., GUIMARÃES-SILVA A.K., NALINI JÚNIOR H.A., PACHECO-SILVA E., LENA J.C. 2007. Distribuição, fracionamento e mobilidade de elementos-traço em sedimentos superficiais. Química Nova, 30:1249-1255.

PETRUNIC B.M., MACQUARRIE K.T.B., ; AL T.A. 2005. Reductive dissolution of Mn oxides in river-recharged aquifers: a laboratory column study. Journal of Hydrology, 301:163-181.

QUINÁGLIA G.A. 2006. Caracterização dos níveis basais de concentração de metais nos sedimentos do Sistema Estuarino da Baixada Santista. Instituto de Química, Universidade de São Paulo, 239 p.

RAURET G. 1998. Extraction procedures for the determination of heavy metals in contaminated soil and sediment. Talanta, 46:449-455.

RAURET G., LOPEZ-SANCHEZ J.F., LUCK D., YLI-HALLA M., MUNTAU H., QUEVAUVILLER P. 2001. The certification of the extractable contents (mass fractions) of $\mathrm{Cd}$, $\mathrm{Cr}, \mathrm{Cu}, \mathrm{Ni}, \mathrm{Pb}$ and $\mathrm{Zn}$ in freshwater sediment following sequential extraction procedure-BCR 701. Bruxelles: BCR Information European Commission. BCR Information. Reference Materials Report EUR 19775.

REDDY K.J., WANG L., ; GLOSS S.P. 1995. Solubility and mobility of copper, zinc and lead in acidic environments. Plant and Soil, 171: 5358.

RIEUWERTS J.S., THORNTON I., FARAGO M.E., ; ASHMORE M.R. (1998). Factors influencing metal bioavailability in soils: preliminary investigations for the development of a critical loads approach for metals. Chemical Speciation ; Bioavailability, 10:61-75.

RODRIGUES A.S.L., JUNIOR H.A.N., COSTA A.T., MALAFAIA G. 2015a. Construção de mapas geoquímicos a partir de sedimentos ativos de margens oriundos do Rio Gualaxo do Norte, MG, Brasil. Multi-Science Journal, 1:7078.

RODRIGUES A.S.L., MALAFAIA G., COSTA A.T., ; NALINI-JR H.A. 2015b. Fractionation of chemical elements from the alluvial terraces and cutbanks of the gualaxo do norte basin, eastern-southeastern of the Quadrilátero Ferrífero, MG, Brazil. Revista de Ciências Ambientais, 8:21-36.

RUIZ F. 2001. Trace metals in estuarine sediments from the southwestern Spanish coast. Marine Pollution Bulletin, 42:481-489.

SÁENZ V., BLASCO J., ; GÓMEZ-PARRA A. 2003. Speciation of heavy metals in recent sediments of three coastal ecosystems in the Gulf of Cádiz, Southwest Iberian Peninsula. Environmental Toxicology and Chemistry, 22:2833-2839.

SALOMONS W. 1998. Biogeodynamics of contaminated sediments and soils: perspectives for future research. Journal of Geochemical Exploration, 62:37-40.

SALOMONS W., ; STIGLIANI W.M. (Eds.). 1995. Biogeodynamics of pollutants in soils and sediments: risk assessment of delayed and nonlinear responses. Springer Science ; Business Media.

SHARMIN S., ZAKIR H.M., ; SHIKAZONO N. 2010. Fractionation profile and mobility pattern of trace metals in sediments of Nomi River, Tokyo, Japan. Journal of Soil Science and Environmental Management, 1:1-14.

SILVA A.P.S., DIAS H.C.T., BASTOS R.K.X., SILVA E. 2009. Qualidade da água do reservatório da usina hidrelétrica (UHE) de Peti, Minas Gerais. Revista Árvore 33:1063-1069.

SINGH K.P., MOHAN D., SINGH V.K., ; MALIK A. 2005. Studies on distribution and fractionation of heavy metals in Gomti river sediments - a tributary of the Ganges, India. Journal of hydrology, 312;14-27.

SMITH K.S., ; HUYCK H.L. (1999). An overview of the abundance, relative mobility, bioavailability, and human toxicity of metals. The environmental geochemistry of mineral deposits, 6:29-70.

TACK F.M., CALLEWAERT O.W.J.J., ; VERLOO M.G. 1996. Metal solubility as a function of $\mathrm{pH}$ in a contaminated, dredged sediment affected by oxidation. Environmental pollution, 91:199-208.

TESSIER A., CAMPBELL P.G., ; BISSON M. 1979. Sequential extraction procedure for the speciation of particulate trace metals. Analytical chemistry, 51:844-851.

TRIBOVILLARD N., ALGEO T.J., LYONS T., ; RIBOULLEAU A. 2006. Trace metals as paleoredox and paleoproductivity proxies: an update. Chemical Geology, 232:12-32.

URE A.M. ; DAVIDSON C.M. (Eds.). 2008. Chemical speciation in the environment. John Wiley; Sons 
URE A.M., QUEVAUVILLER P.H., MUNTAU H., ; Griepink B. 1993. Speciation of heavy metals in soils and sediments. An account of the improvement and harmonization of extraction techniques undertaken under the auspices of the BCR of the Commission of the European Communities. International journal of environmental analytical chemistry, 51:135-151.

VIOLANTE A., COZZOLINO V., PERELOMOV L., CAPORALE A.G., ; PIGNA M. 2010. Mobility and bioavailability of heavy metals and metalloids in soil environments. Journal of soil science and plant nutrition, 10:268-292.

WARREN L.A., ; HAACK E.A. 2001. Biogeochemical controls on metal behaviour in freshwater environments. Earth-Science Reviews, 54:261-320.

YACOUB C., PÉREZ-FOGUET A., ; MIRALLES N. 2012. Trace metal content of sediments close to mine sites in the Andean region. The Scientific World Journal, 2012:1-12.

YANG J., CAO L., WANG J., LIU C., HUANG C.,
CAI W., ; PENG, X. 2014. Speciation of metals and assessment of contamination in surface sediments from Daya Bay, South China Sea. Sustainability, 6:9096-9113.

YUAN C.G., SHI J.B., HE B., LIU J.F., LIANG L.N., ; JIANG G.B. 2004. Speciation of heavy metals in marine sediments from the East China Sea by ICP-MS with sequential extraction. Environment International, 30:769-783.

ZHANG C., YU Z.G., ZENG G.M., JIANG M., YANG Z.Z., CUI F., HU L. 2014. Effects of sediment geochemical properties on heavy metal bioavailability. Environment international, 73:270-281.

ZHANG L., LIAO Q., SHAO S., ZHANG N., SHEN Q., ; LIU C. 2015. Heavy metal pollution, fractionation, and potential ecological risks in sediments from Lake Chaohu (Eastern China) and the surrounding rivers. International journal of environmental research and public health, 12:14115-14131. 